\title{
A Canker Disease of Populus $\times$ euramericana in China Caused by Lonsdalea quercina subsp. populi
}

Yong Li, The Key Laboratory for Silviculture and Conservation of Ministry of Education, Beijing Forestry University, Beijing 100083, and The Key Laboratory of State Forestry Administration on Forest Protection, Research Institute of Forest Ecology Environment and Protection, Chinese Academy of Forestry, Beijing 100091; Wei He and Feijuan Ren, The Key Laboratory for Silviculture and Conservation of Ministry of Education, Beijing Forestry University, Beijing 100083; Limin Guo and Jupu Chang, Forestry Research Institute of Puyang, Henan Puyang, China; Ilse Cleenwerck, BCCM/LMG Bacteria Collection, Ghent University, Laboratory of Microbiology, K. L. Ledeganckstraat 35, B-9000 Ghent, Belgium; Yuchao Ma, Beijing Forestry University, Beijing 100083; and Haiming Wang, Forest Protection Station, Heze, Shandong province, China

\begin{abstract}
Li, Y., He, W., Ren, F., Guo, L., Chang, J., Cleenwerck, I., Ma, Y., and Wang, H. 2014. A canker disease of Populus $\times$ euramericana in China caused by Lonsdalea quercina subsp. populi. Plant Dis. 98:368-378.

In 2006, a new canker was observed on trees of Populus $\times$ euramericana '74/76' and $P . \times$ euramericana 'Zhonglin 46 ' in the Henan and Shandong provinces of China. The disease, which is characterized by canker with white exudates dripping from the bark, occurred mainly in the summer. A particular gram-negative, rod-shaped bacterium was repeatedly isolated from the infected samples and proven to infect trees

of $P . \times$ euramericana by Koch's postulates. Through a polyphasic taxonomic approach using sequence, DNA-DNA hybridization, chemotaxonomic, and phenotypic data, the poplar isolates were identified as Lonsdalea quercina subsp. populi, a subspecies very recently described based on isolates from oozing bark canker of poplar $(P . \times$ euramericana) trees in Hungary.
\end{abstract}

Populus $\times$ euramericana, an interspecific hybrid poplar between Populus nigra and P. deltoids, was introduced into China in the 1980 s and has become one of the most widely grown trees in China, mainly due to its fast-growing nature and good wood property as paper pulp. In 2006, poplar trees more than 5 years old showing bark canker with abundant white, sour exudates were observed for the first time in China's Henan and Shandong provinces. Diseased plants had stem or branch bark that cracked and exuded frothy fluid and, when the disease progressed, many cankers (50 to 150 by 3 to $8 \mathrm{~cm}$, width by length) rapidly appeared (Fig. 1). In serious cases, diseased trees even died.

Four cultivars of $P . \times$ euramericana were found with this bark canker disease in China. Of four susceptible cultivars, $P . \times$ euramericana 'Zhonglin 46 ' is the most susceptible, with disease incidence up to $70 \%$ in some stands. Cultivars ' $74 / 76$ ' and $P$. deltoides 'Zhonghe 1' are intermediate, with up to $50 \%$ disease incidence in the most serious cases. P. $\times$ euramericana 'Robusta' seems relatively resistant, with disease incidence up to $5 \%$ in a pure stand of 9-year-old trees. The resistance of other poplar cultivars in China to this disease has not been investigated.

In a preliminary report (13), the fungus Fusarium solani was identified as the causal agent of this canker disease. This conclusion was based on inoculation of water-cultured excised stem of $P$. $\times$ euramericana $74 / 76$ in a greenhouse $\left(28^{\circ} \mathrm{C}\right.$ incubator $)$, in which a F. solani strain, isolated from canker tissue, proved to be pathogenic. However, when $F$. solani was subsequently tested in field experiments during the course of this study, symptoms at inoculation points of $P \times$ euramericana $74 / 76$ and $P \times$ euramericana Zhonglin 46 trees were not typical of naturally infected trees. This result indicated that $F$. solani alone was not the causal agent.

Corresponding author: W. He, E-mail: hewei@bjfu.edu.cn

The first and second authors contributed equally to this work.

Accepted for publication 25 September 2013.

http://dx.doi.org/10.1094/PDIS-01-13-0115-RE

(c) 2014 The American Phytopathological Society
In the $1990 \mathrm{~s}$, poplar trees $(P . \times$ euramericana $)$ showing bark cankers with copious brownish exudations, somewhat similar to the disease in China, were observed in several plantations in Spain $(3,4)$. The causal agent of these cankers was identified as "Brenneria populi" using API 20E, API 20NE, API 50CH, API ZYM, and fatty acid analyses (4). The genus Brenneria, which was established in $1998(11,12)$, was originally composed of six recognized species (B. alni, B. nigrifluens, B. paradisiaca, B. quercina, $B$. rubrifaciens, and $B$. salicis) that cause blight canker, wilt, and necrosis of various trees, including oak, willow, and walnut $(2,10,15,22)$. Recently, B. quercina was transferred into a novel genus, Lonsdalea, as Lonsdalea quercina comb. nov., and three subspecies were described based on isolates that were proven or supposed pathogens of oak trees ( $L$. quercina subsp. quercina, $L$. quercina subsp. iberica, and L. quercina subsp. britannica; 5). Very recently, a fourth subspecies was described (L. quercina subsp. populi) for isolates from oozing bark canker of $P . \times$ euramericana trees in Hungary (25).

In order to determine the real causal agent of the poplar canker disease observed in China, more samples were investigated using different methods of isolation, and inoculation tests were performed in both the greenhouse and the field. In addition, " $B$. populi" National Collection of Plant-Pathogenic Bacteria (NCPPB, Food and Environment Research Agency, Sand Hutton, York, UK) 4299 of $P$. $\times$ euramericana causing bark canker in Spain, $L$. quercina subsp. quercina American Type Culture Collection (ATCC) $29281^{\mathrm{T}}$ of Quercus sp. causing drippy nut disease in the United States, L. quercina subsp. iberica LMG 26264 ${ }^{\mathrm{T}}$ (Belgian Coordinated Collections of Microorganisms [BCCM]/LMG Bacteria Collection, Ghent University, Belgium) from Quercus ilex showing bark canker in Spain, and L. quercina subsp. britannica LMG $26267^{\mathrm{T}}$ of $Q$. ruber causing acute oak decline in Britain were also selected for field inoculation. The microorganisms that were pathogenic in the field experiment were subjected to a polyphasic taxonomic analysis.

\section{Materials and Methods}

Isolation of the pathogen. Diseased poplar tissues of $P . \times$ euramericana 74/76 and Zhonglin 46 were collected between 2009 and 2010 from three locations in Henan and Shandong provinces. 
Samples collected in the field were transferred to laboratories of the Beijing Forestry University in Beijing for isolation. Samples from asymptomatic poplar trees were also collected. The tissue from poplar stems was surface disinfected with $4.5 \%$ sodium hypochlorite, washed three times with sterile water, and cut into 3-by-3$\mathrm{mm}$ segments with a sterile razor blade. Tissue segments were then put in a tube containing $5 \mathrm{ml}$ of sterile distilled water (SDW) and shaken for about $10 \mathrm{~min}$. The resulting suspension was serially diluted in SDW and spread onto nutrient agar medium. After incubation at $30^{\circ} \mathrm{C}$ for 2 days, single bacterial colonies were selected for subculturing to obtain pure cultures for storage and identification.

Pathogenicity tests in poplars. Pathogenicity tests were first conducted on water-cultured excised stems in a greenhouse $\left(28^{\circ} \mathrm{C}\right.$ incubator), after which the isolates that induced canker symptoms were tested in field studies.

In a greenhouse at Beijing Forestry University, stems of 2-yearold water-cultured seedlings of $P . \times$ euramericana $74 / 76$ or Zhonglin 46 were cut into $30-\mathrm{cm}$-long segments and the top ends wrapped with plastic film to prevent desiccation. The segments were inoculated and placed in a tray that was subsequently covered with parafilm (Sunway Kordis Ltd.) to retain humidity. The segments were kept in darkness at $28^{\circ} \mathrm{C}$, and the canker length and width were measured 14 days after inoculation.

In a field study at the Experimental Station of the Forestry Research Institute of Puyang, Henan province (where the disease occurs naturally), 3-, 4-, or 5-year-old trees of P. $\times$ euramericana $74 / 76$ or Zhonglin 46 were inoculated with pure cultures of isolates that induced canker symptoms in the greenhouse. In addition, $B$. populi NCPPB 4299, L. quercina subsp. quercina ATCC $29281^{\mathrm{T}}$, L. quercina subsp. iberica LMG $26264^{\mathrm{T}}$, and L. quercina subsp. britannica LMG $26267^{\mathrm{T}}$ were used in the field studies. Field inoculations were executed in the bark on the stem of the trees, and the wounds were wrapped with plastic foil for 3 days and then unwrapped.

Each bacterial strain was inoculated on six stems of 2-year-old seedlings in the greenhouse, and on the stems of six trees of one cultivar in the same forest plantation. Prior to inoculation, each strain was grown in Luria-Bertani medium at $30^{\circ} \mathrm{C}$ for $24 \mathrm{~h}$ and then centrifuged for $10 \mathrm{~min}$ at $11,700 \times g$ to pellet the cells. The cells were resuspended in SDW and adjusted to a concentration of $10^{7} \mathrm{CFU} / \mathrm{ml}$ before inoculation. Bark was surface disinfected with $75 \%$ ethanol, before cross-shaped wounds $(5 \mathrm{~mm}$ long in the greenhouse and $2 \mathrm{~cm}$ long in the field) were made in the bark (in the middle of the segments in the greenhouse or at a height of 1.5 $\mathrm{m}$ on the stem of trees in the field) with a sterile knife. The suspension of bacteria $(100 \mu \mathrm{l}$ per site) was introduced into the wound with a sterile dropper. Control plants were treated with SDW only.

Field inoculations were conducted from June to September 2009 to 2012, when air temperature in the field was suitable for disease development. Poplar isolate N-5-1, obtained in 2009, was inoculated in the field in 2009. In 2010, isolates N-5-1, 4-4, and HZ1031, the latter two obtained in 2010, were inoculated in the field in $P$. $\times$ euramericana Zhonglin 46. In 2011, strains N-5-1 and 4-4 were inoculated on $P$. $\times$ euramericana $74 / 76$ to test their
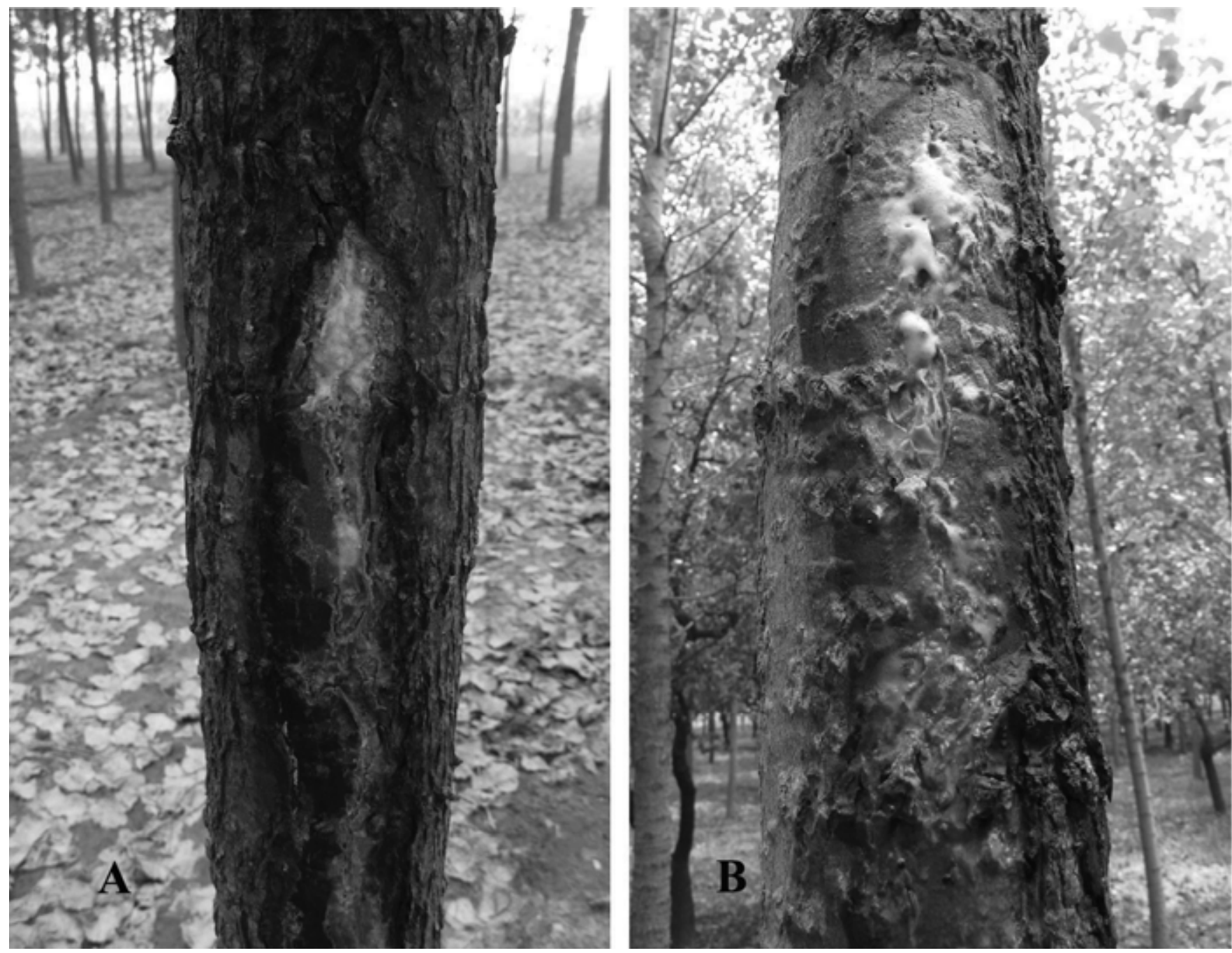

Fig. 1. Symptoms of canker disease of Populus $\times$ euramericana '74/76' caused by Lonsdalea quercina subsp. populi and observed in the field in Puyang city, Henan province. A, Initial symptoms with abundant white, sour exudate; B, medium-term symptoms 3 weeks after initial appearance. 
pathogenicity to this cultivar. The reference strains $B$. populi NCPPB 4299, L. quercina subsp. quercina ATCC $29281^{\mathrm{T}}$, L. quercina subsp. iberica $\mathrm{LMG} 26264^{\mathrm{T}}$, and L. quercina subsp. britannica LMG $26267^{\mathrm{T}}$ were tested in the field in 2012 on $P . \times$ euramericana Zhonglin 46 . Strain N-5-1 was then used as a positive control. The results of the field pathogenicity tests were re- corded 10, 20, and 30 days after inoculation. Diseased poplar tissue was sampled for reisolation of the inoculated bacteria.

Strains and DNA extraction. The poplar isolates and reference strains investigated in this study are listed in Table 1. Reference strains were obtained from the BCCM/LMG, NCPPB, and ATCC. All bacterial strains were cultured on tryptic soy agar (TSA; Ox-

Table 1. Poplar strains of Lonsdalea and reference bacterial strains investigated in this study

\begin{tabular}{|c|c|c|c|c|c|c|c|}
\hline \multirow[b]{2}{*}{ Species, strain ${ }^{b}$} & \multirow[b]{2}{*}{ Source } & \multirow[b]{2}{*}{ Location } & \multicolumn{5}{|c|}{ GenBank accession numbers ${ }^{a}$} \\
\hline & & & gyrB & rрoB & infB & atpD & $\operatorname{gapA}$ \\
\hline \multicolumn{8}{|c|}{ Lonsdalea quercina subsp. populi } \\
\hline LMG $27349^{\mathrm{T}}=\mathrm{NY} 060^{\mathrm{T}}$ & Populus $\times$ euramericana & Mikebuda, Hungary & JQ291581 & KC481243\# & JQ291584 & JQ291578 & KC481244\# \\
\hline LMG $27397=$ NY011 & P. $\times$ euramericana & Mikebuda, Hungary & JQ291579 & KF279544\# & JQ291582 & JQ291576 & 1 \\
\hline LMG 27396= NY041 & P. $\times$ euramericana & Mikebuda, Hungary & JQ291580 & KF279545\# & JQ291583 & JQ291577 & I \\
\hline $\mathrm{N}-5-1$ & P. $\times$ euramericana & Henan, China & JX392905\# & JX392900\# & JX392895\# & JX392910\# & JF424603\# \\
\hline $4-4$ & P. $\times$ euramericana & Henan, China & JX392906\# & JX392901\# & JX392896\# & JX392911\# & JX39288325\# \\
\hline PY7-2 & P. $\times$ euramericana & Henan, China & JX392907\# & JX392902\# & JX392897\# & JX392912\# & JX39288425\# \\
\hline HZ1031 & P. $\times$ euramericana & Shandong, China & JX392908\# & JX392903\# & JX392898\# & JX392913\# & JX499271\# \\
\hline $107-18$ & P. $\times$ euramericana & Shandong, China & JX392909\# & JX392904\# & JX392899\# & JX392914\# & JX 499270\# \\
\hline \multicolumn{8}{|c|}{ Brenneria quercina pv. lupinicola } \\
\hline W3L1 & Lupinus albus & United States & l & l & I & / & / \\
\hline W3L7 & L. albus & United States & l & l & I & / & I \\
\hline W3L8 & L. albus & United States & l & l & I & I & I \\
\hline W3L22 & L. leucophyllus & United States & l & I & I & / & I \\
\hline \multicolumn{8}{|c|}{ Lonsdalea quercina subsp. quercina } \\
\hline ATCC $29281^{\mathrm{T}}$ & Quercus agrifoli & United States & JF311656 & JF311881 & JF311769 & JF311543 & JX39287725\# \\
\hline LMG 2725 & Quercus sp. & United States & JF311657 & JF311882 & JF311770 & JF311544 & JX39287825\# \\
\hline LMG 5952 & Quercus sp. & United States & JF311660 & JF311885 & JF311773 & JF311547 & l \\
\hline \multicolumn{8}{|l|}{ L. quercina subsp. iberica } \\
\hline LMG $26264^{\mathrm{T}}$ & Q. ilex & Madrid, Spain & JF311665 & JF311890 & JF311778 & JF311552 & JX39288025\# \\
\hline LMG 26265 & Q.pyrenaica & Madrid, Spain & JF311662 & JF311887 & JF311775 & JF311549 & JX39287925\# \\
\hline LMG 26266 & Q. ilex & Madrid, Spain & JF311663 & JF311888 & JF311776 & JF311550 & / \\
\hline \multicolumn{8}{|l|}{ L. quercina subsp. britannica } \\
\hline LMG $26267^{\mathrm{T}}$ & Q. robur & Booth Wood, UK & JF311666 & JF311891 & JF311779 & JF311553 & JX39288225\# \\
\hline LMG 26268 & Q. robur & Booth Wood, UK & JF311667 & JF311892 & JF311780 & JF311554 & JX39288125\# \\
\hline LMG 26269 & Q. robur & Gorse Covert, UK & JF311669 & JF311894 & JF311782 & JF311556 & 1 \\
\hline \multicolumn{8}{|l|}{ B. populi } \\
\hline NCPPB 4296 & P. $\times$ euramericana & Spain & l & l & I & / & JX39287025\# \\
\hline NCPPB 4297 & P. $\times$ euramericana & Spain & l & I & I & / & JX39286925\# \\
\hline NCPPB $4299^{\mathrm{T}}$ & P. $\times$ euramericana & Spain & I & I & I & I & JX39286825\# \\
\hline \multicolumn{8}{|l|}{ B. alni } \\
\hline NCPPB $3934^{\mathrm{T}}$ & Alnus cordata & Italy & JF311627 & JF311852 & JF311740 & JF311514 & JX39286525\# \\
\hline B. nigrifluens & & & & & & & \\
\hline LMG $2694^{\mathrm{T}}$ & Juglans regia & United States & JF311612 & JF311837 & JF311725 & JF311499 & JX39286525\# \\
\hline B. rubrifaciens & & & & & & & \\
\hline LMG $2709^{\mathrm{T}}$ & J. regia & United States & JF311617 & JF311842 & JF311730 & JF311504 & JX39286725\# \\
\hline B. salicis & & & & & & & \\
\hline LMG $2698^{\mathrm{T}}$ & Salix alba & United Kingdom & JF311622 & JF311847 & JF311735 & JF311509 & JF424605\# \\
\hline Dickeya chrysanthemi & & & & & & & \\
\hline LMG $2804^{\mathrm{T}}$ & Dianthus caryophyllus & United Kingdom & JF311636 & JF311861 & JF311749 & JF311523 & JX39287125\# \\
\hline Dickeya dadantii subsp. die & & & & & & & \\
\hline LMG $25992^{\mathrm{T}}$ & Dieffenbachia sp. & United States & JF311652 & JF311877 & JF311765 & JF311539 & GQ891968 \\
\hline Dickeya dianthicola & & & & & & & \\
\hline LMG $2485^{\mathrm{T}}$ & Dianthus caryophyllus & United Kingdom & JF311648 & JF311873 & JF311761 & JF311535 & JX39287325\# \\
\hline Dickeya paradisiaca & & & & & & & \\
\hline LMG $2542^{\mathrm{T}}$ & Musa paradisiaca & Colombia & JF311640 & JF311865 & JF311753 & JF311527 & JX39287225\# \\
\hline Erwinia amylovora & & & & & & & \\
\hline LMG $2024^{\mathrm{T}}$ & Pyrus communis & United Kingdom & HQ393608 & HQ393632 & HQ393620 & HQ393596 & JX39287425\# \\
\hline E. mallotivora & & & & & & & \\
\hline LMG $2708^{\mathrm{T}}$ & Mallotus japonicus & Japan & HQ393601 & HQ393625 & HQ393613 & HQ393589 & JX39287525\# \\
\hline E. pyrifoliae & & & & & & & \\
\hline LMG $25888^{\mathrm{T}}$ & Pyrus pyrifolia & South Korea & HQ393609 & HQ393633 & HQ393621 & HQ393597 & NC_017390 \\
\hline E. tracheiphila & & & & & & & \\
\hline LMG $2906^{\mathrm{T}}$ & Cucumis melo & United States & HQ393603 & HQ393627 & HQ393615 & HQ393591 & JX39287625\# \\
\hline Pantoea agglomerans & & & & & & & \\
\hline LMG $1286^{\mathrm{T}}$ & Human & Zimbabwe & EF988798 & EF988970 & EF988884 & EF988711 & JX39288525\# \\
\hline P. anthophila & & & & & & & \\
\hline LMG $2558^{\mathrm{T}}$ & Impatiens balsamina & India & EF988812 & EF988984 & EF988898 & EF988725 & JX39288625\# \\
\hline P. cypripedii & & & & & & & \\
\hline LMG $2657^{\mathrm{T}}$ & Cypripedium sp. & United States & FJ187830 & FJ187840 & FJ187835 & FJ187825 & JX39288725\# \\
\hline P. stewartii subsp. stewarti & & & & & & & \\
\hline LMG $2715^{\mathrm{T}}$ & Zea mays & United States & EF988831 & EF989003 & EF988917 & EF988744 & JX39288825\# \\
\hline Pectobacterium wasabiae & & & & & & & \\
\hline LMG $8444^{\mathrm{T}}$ & Eutrema wasabi & Japan & JF311608 & JF311833 & JF311721 & JF311495 & FJ895855 \\
\hline P. carotovorum subsp. care & & & & & & & \\
\hline LMG $2404^{\mathrm{T}}$ & Solanum tuberosum & Denmark & JF311601 & HM359006 & JF311714 & JF311488 & JX392889\# \\
\hline
\end{tabular}

${ }^{\text {a }}$ Symbols: \# = sequences determined in this study and / = sequences not available.

${ }^{\mathrm{b}}$ LMG = BCCM/LMG Bacteria Collection, Ghent University, Belgium; ATCC = American Type Culture Collection, Manassas, KS; and NCPPB = National Collection of Plant Pathogenic Bacteria, Food and Environment Research Agency, Sand Hutton, York, United Kingdom. 
oid) at $30^{\circ} \mathrm{C}$ for $24 \mathrm{~h}$. Genomic DNA for polymerase chain reaction (PCR) was extracted from bacterial cells using the cetyltrimethylammonium bromide protocol (1).

PCR amplification and DNA sequencing. The following genes were studied: the 16S ribosomal RNA (rRNA) gene; glyceraldehyde-3-phosphate dehydrogenase A (gapA); DNA gyrase B subunit $($ gyrB $)$; RNA polymerase, $\beta$ subunit $(r p o B)$; initiation translation factor 2 (infB); and ATP synthase F1, $\beta$ subunit (atpD). The $16 \mathrm{~S}$ rRNA gene of five poplar isolates obtained during this study and three $B$. populi strains obtained from NCPPB were amplified from genomic DNA using the universal primers 27f/1492r. Amplification and sequencing were performed as previously published (14). Amplification and sequencing of the gapA gene was performed for the same five poplar isolates and selected strains of species belonging to the genera Lonsdalea, Brenneria (including $B$. populi), Erwinia, Dickeya, Pantoea, and Pectobacterium, as previously described (17). Amplification and sequencing of gyrB, rpoB, inf $B$, and $a t p D$ were performed for the five poplar isolates, as previously described $(5,6)$.

Phylogenetic analyses. Almost complete 16S rRNA gene sequences of the five poplar isolates and the three " $B$. populi" strains were compared with those of reference strains of species belonging to the genera Lonsdalea, Brenneria, Erwinia, Dickeya, Pantoea, and Pectobacterium downloaded from GenBank. The sequences were aligned using ClustalW (24) and MEGA5.1 (http://www. megasoftware.net) (23). Neighbor-joining, maximum parsimony, and maximum likelihood trees were constructed using MEGA 5.1. A bootstrap analysis with 1,000 replicates was performed to test the stability on randomly chosen sets of positions.

Partial gapA gene sequences determined in this study were compared with sequences of species belonging to the same genera as selected for the 16S rRNA gene sequence analyses downloaded from GenBank. Sequence analysis and tree construction were executed as described for the 16S rRNA gene sequences.

Multilocus sequence analysis (MLSA) was conducted using partial sequences of $g y r B, r p o B, \inf B$, and $a t p D$ determined in this study or downloaded from GenBank (for reference strains of species belonging to the genera Lonsdalea, Brenneria, Erwinia, Dickeya, and Pectobacterium). Analysis based on each single nucleotide gene sequence was also performed. Sequence analysis and tree construction were executed on the concatenated data set as described for the 16S rRNA gene sequences.

DNA-DNA hybridization and DNA $\mathbf{G}+\mathbf{C}$ content. Two isolates from poplar canker in Puyang city (N-5-1 and 4-4); one isolate from poplar canker in Heze city (HZ1031); and the type strains of L. quercina subsp. populi LMG $27349^{\mathrm{T}}$, L. quercina subsp. quercina ATCC $29281^{\mathrm{T}}$, L. quercina subsp. iberica LMG $26264^{\mathrm{T}}$ and $L$. quercina subsp. britannica $\mathrm{LMG} 26267^{\mathrm{T}}$ were selected for DNA-DNA hybridization experiments. DNA for these experiments was extracted and purified using the method described by Marmur (18). The initial renaturation rate method was used for DNA-DNA hybridization as described by De Ley et al. (8). The DNA-DNA relatedness values presented are based on a minimum of three replicates. The DNA $\mathrm{G}+\mathrm{C}$ content of the same three poplar canker isolates was determined using the thermal denaturation protocol, as described by De Ley et al. (8).

Fatty acid analysis. Fatty acid profiles were determined for the poplar canker isolate $\mathrm{N}-5-1$ and the type strains of the subspecies of L. quercina (LMG $27349^{\mathrm{T}}$, ATCC $29281^{\mathrm{T}}$, LMG $26264^{\mathrm{T}}$, and LMG $26267^{\mathrm{T}}$ ) using identical conditions. Cultivation of the strains, extraction, and analysis of the fatty acid methyl esters were performed according to the recommendations of the Microbial Identification System (20), Sherlock version 3.10 (MIDI). Extraction of the fatty acids was done from cells grown on TSA for $24 \mathrm{~h}$ at $28^{\circ} \mathrm{C}$. Peaks of the profiles were identified using TSBA50 identification library version 5.0.

Phenotypic tests. The poplar canker isolates obtained in this study were cultured for $24 \mathrm{~h}$ on TSA (Oxoid) at $30^{\circ} \mathrm{C}$ for colony characterization. Initial tests for identification included Gram stain, flagella stain, ability to grow as a facultative anaerobe, catalase test, $\mathrm{H}_{2} \mathrm{~S}$ and indole production test, oxidase test, cellulose-degrading enzyme test, Voges-Proskauer test, and amylase test. All tests were performed as described $(9,26)$. Commercial biochemical tests API 20E, API 50CHB/E (bioMérieux), and BIOLOG GN2 plates (Biolog) were also performed on the five poplar canker isolates and on the type strains of the subspecies of L. quercina as described in the manufacturer's instructions. All tests were performed at least twice in different sessions and repeated when inconsistent results were obtained.

\section{Results}

Isolation of the pathogen. More than 10 different bacterial colony types were isolated; however, 1 circular, domed, and whitishcolor colony type was dominant. Five isolates of this colony type (N-5-1 = LMG 27203, 107-18, 4-4, HZ1031, and PY7-2, with N-5-1 selected as representative strain) were obtained; among them, one isolate (107-18) was from an asymptomatic poplar. In all samples collected from the different locations in Puyang city, Henan province, bacteria like N-5-1 were consistently isolated from diseased poplar bark tissues, whereas only one such isolate (107-18)

Table 2. Pathogenicity tests of bacteria strains for Populus $\times$ euramericana in greenhouse and in field experiments

\begin{tabular}{|c|c|c|c|c|c|c|c|c|c|c|c|c|c|}
\hline \multirow[b]{3}{*}{ Date } & \multirow[b]{3}{*}{ Cultivar $^{\mathbf{b}}$} & \multirow[b]{3}{*}{ Time $^{c}$} & \multicolumn{11}{|c|}{ Strains $^{a}$} \\
\hline & & & \multicolumn{2}{|l|}{1} & \multicolumn{2}{|l|}{2} & \multicolumn{2}{|l|}{3} & \multirow{2}{*}{$\frac{4}{N}$} & \multirow{2}{*}{$\frac{5}{N}$} & \multirow{2}{*}{$\begin{array}{c}6 \\
N\end{array}$} & \multirow{2}{*}{$\begin{array}{c}7 \\
N\end{array}$} & \multirow{2}{*}{$\begin{array}{c}\mathbf{8} \\
N\end{array}$} \\
\hline & & & Lesion (cm) & $N$ & Lesion (cm) & $N$ & Lesion (cm) & $N$ & & & & & \\
\hline 2009-08-04 & 2-year-old stem, 74/76 & 14 & $3-9 \times 1-3$ & $6 / 6(\mathrm{re})$ & $\cdots$ & $\cdots$ & $\cdots$ & $\cdots$ & $\cdots$ & $\cdots$ & $\cdots$ & $\cdots$ & $0 / 6$ \\
\hline \multirow[t]{3}{*}{ 2009-09-05 } & 3-year-old tree, ZL 46 & 10 & $5-7.9 \times 3.4-5$ & $6 / 6(\mathrm{re})$ & $\cdots$ & $\cdots$ & $\cdots$ & $\cdots$ & $\ldots$ & $\cdots$ & $\ldots$ & $\ldots$ & $0 / 6$ \\
\hline & & 20 & $9-18.2 \times 4.2-7.1$ & $6 / 6$ & $\ldots$ & $\ldots$ & $\ldots$ & $\ldots$ & $\ldots$ & $\ldots$ & $\ldots$ & $\ldots$ & $\ldots$ \\
\hline & & 30 & $13-25.2 \times 5-7.6$ & $6 / 6$ & $\ldots$ & $\ldots$ & $\ldots$ & $\ldots$ & $\ldots$ & $\ldots$ & $\ldots$ & $\ldots$ & $\ldots$ \\
\hline 2010-06-16 & 2-year-old stem, 74/76 & 14 & $3.5-8 \times 1.1-2.5$ & $5 / 6$ & $3.5-8.5 \times 2.3-4.5$ & $6 / 6(\mathrm{re})$ & $4.2-8.6 \times 3.5-4.7$ & $6 / 6(\mathrm{re})$ & $\ldots$ & $\ldots$ & $\ldots$ & $\ldots$ & $0 / 6$ \\
\hline \multirow[t]{3}{*}{ 2010-06-28 } & 5-year-old tree, ZL 46 & 10 & $4-7.2 \times 3.6-4.5$ & $6 / 6$ & $3.6-9 \times 2.6-4.4$ & $6 / 6$ & $4.5-8 \times 3.8-4.5$ & $6 / 6$ & $\ldots$ & $\ldots$ & $\ldots$ & $\ldots$ & $0 / 6$ \\
\hline & & 20 & $8-12 \times 4.1-5.8$ & $6 / 6$ & $5-12.4 \times 3.1-6.3$ & $6 / 6$ & $7-12.5 \times 4.4-5.6$ & $6 / 6$ & $\ldots$ & $\ldots$ & $\ldots$ & $\ldots$ & $\ldots$ \\
\hline & & 30 & $14-20 \times 4.8-7$ & $6 / 6$ & $16-20 \times 5.2-7.1$ & $6 / 6$ & $11-17 \times 4.8-7.7$ & $6 / 6$ & $\ldots$ & $\ldots$ & $\ldots$ & $\ldots$ & $\ldots$ \\
\hline \multirow[t]{3}{*}{ 2011-08-05 } & 5 -year-old tree, $74 / 76$ & 10 & $8-13.9 \times 4.6-5.6$ & $6 / 6$ & $5.6-9 \times 3.6-5.2$ & $6 / 6$ & $\cdots$ & $\cdots$ & $\cdots$ & $\cdots$ & $\ldots$ & $\ldots$ & $0 / 6$ \\
\hline & & 20 & $12-25 \times 5.2-7.2$ & $6 / 6$ & $11-21.4 \times 4.1-7.3$ & $6 / 6$ & $\ldots$ & $\ldots$ & $\ldots$ & $\ldots$ & $\ldots$ & $\ldots$ & $\ldots$ \\
\hline & & 30 & $14-32 \times 5.2-8$ & $6 / 6$ & $13-26 \times 5-7.8$ & $6 / 6$ & $\ldots$ & $\ldots$ & $\ldots$ & $\ldots$ & $\ldots$ & $\ldots$ & $\ldots$ \\
\hline $2012-7-28$ & 2-year-old stem, ZL 46 & 14 & $4-10 \times 1-2$ & $6 / 6$ & $\ldots$ & $\ldots$ & $\ldots$ & $\ldots$ & $0 / 6$ & $0 / 6$ & $0 / 6$ & $0 / 6$ & $0 / 6$ \\
\hline \multirow[t]{3}{*}{$2012-8-19$} & 4-year-old tree, ZL 46 & 10 & $4.6-18 \times 2.7-5.2$ & $6 / 6$ & $\ldots$ & $\ldots$ & $\ldots$ & $\ldots$ & $0 / 6$ & $0 / 6$ & $0 / 6$ & $0 / 6$ & $0 / 6$ \\
\hline & & 20 & $12.3-41 \times 4.6-7.2$ & $6 / 6$ & $\ldots$ & $\cdots$ & $\cdots$ & $\ldots$ & $\ldots$ & $\ldots$ & $\cdots$ & $\ldots$ & $\cdots$ \\
\hline & & 30 & $14.2-44 \times 5.1-7.8$ & $6 / 6$ & $\ldots$ & $\ldots$ & $\ldots$ & $\ldots$ & $\ldots$ & $\ldots$ & $\ldots$ & $\ldots$ & $\ldots$ \\
\hline
\end{tabular}

\footnotetext{
${ }^{\mathrm{a}} N=$ number and Lesion $=$ lesion size for strains $1, \mathrm{~N}-5-1 ; 2,4-4 ; 3$ HZ1031; 4, NCPPB 4299; 5, LMG 26264 $; 6, \mathrm{LMG}^{\mathrm{T}} 26267^{\mathrm{T}} ; 7, \mathrm{ATCC}_{2} 29281^{\mathrm{T}} ; 8$, control; re, reisolation.

b Inoculated stem segments and trees of Populus $\times$ euramericana '74/76' and 'Zhonglin 46' (ZL 46).

c Time in days.
} 
was obtained from more than 100 bark samples from asymptomatic poplar collected from 2010 to 2011 . All isolates were purified by repeated dilution streaking and stored in $20 \%$ sterile glycerin at $-70^{\circ} \mathrm{C}$ in the Lab of Forest Pathology of Beijing Forestry University.

Pathogenicity tests in poplar. Of all isolates tested in the greenhouse, three (N-5-1, 4-4, and HZ1031) induced canker symptoms in the inoculated stem segments. Symptoms on the 30-cm-long inoculated segments appeared 4 days after inoculation. Initially, the cortical layers of the inoculation site were macerated. One day later, a yellow-whitish-colored liquid flowed from the inoculation site, and the lesion expanded further in the following days. Inoculation with other isolates obtained in this study and with B. populi NCPPB 4299, L. quercina subsp. quercina ATCC $29281^{\mathrm{T}}$, L. quercina subsp. iberica LMG $26264^{\mathrm{T}}$, L. quercina subsp. britannica $\mathrm{LMG} 26267^{\mathrm{T}}$, and the control did not show formation of water-soaked lesions (Table 2). Necrosis was limited to the wound site.

The three poplar isolates that were pathogenic in the greenhouse study (N-5-1, 4-4, and HZ1031); in addition, B. populi NCPPB 4299, L. quercina subsp. quercina ATCC $29281^{\mathrm{T}}$, L. quercina subsp. iberica LMG $26264^{\mathrm{T}}$, and L. quercina subsp. britannica LMG $26267^{\mathrm{T}}$ were subsequently tested in field studies. Typical field symptoms, including bark canker with abundant white sour exudate, were invariably reproduced with the three bacterial iso- lates (Fig. 2A; Table 2). The development of symptoms paralleled those of natural infections. In addition, the same bacterium obtained through reisolation from the inoculated diseased plants reproduced typical symptoms like those of the natural infection of the disease when inoculated into 5-year-old trees. Typical symptoms were not observed in 4-year-old trees of $P . \times$ euramericana Zhonglin 46 inoculated with NCPPB 4299, ATCC $29281^{\mathrm{T}}$, LMG $26264^{\mathrm{T}}$, or LMG $26267^{\mathrm{T}}$. In addition, the wounds on these inoculated trees healed after 2 weeks (Fig. 2B, C, E, and F, respectively), and the controls remained healthy (Fig. 2D).

Phylogenetic analyses. Pairwise comparison of $16 \mathrm{~S}$ rRNA gene sequences revealed $100 \%$ nucleotide similarity among the sequences of the five poplar isolates N-5-1, 107-18, 4-4, HZ1031, and PY7-2, and 99.7, 99.5, 98.8, and 98.4\% with those of $L$. quercina subsp. populi $\mathrm{NY}^{2} 0^{\mathrm{T}}$, L. quercina subsp. quercina $\mathrm{LMG}$ $2724^{\mathrm{T}}$, L. quercina subsp. iberica LMG $26264^{\mathrm{T}}$, and L. quercina subsp. britannica LMG $26267^{\mathrm{T}}$, respectively. They also showed 98.5 to $98.6 \%$ nucleotide similarity with sequences of strains of $B$. quercina pv. lupinicola, which causes drippy pod disease of white lupine (16). Similarity to other species of the Enterobacteriaceae family was less than $97 \%$. In the $16 \mathrm{~S}$ rRNA gene phylogenetic analyses, three methods yielded congruent trees. As shown in the tree generated using maximum likelihood tree (Fig. 3), the five poplar isolates fall in a large cluster composed of Lonsdalea strains
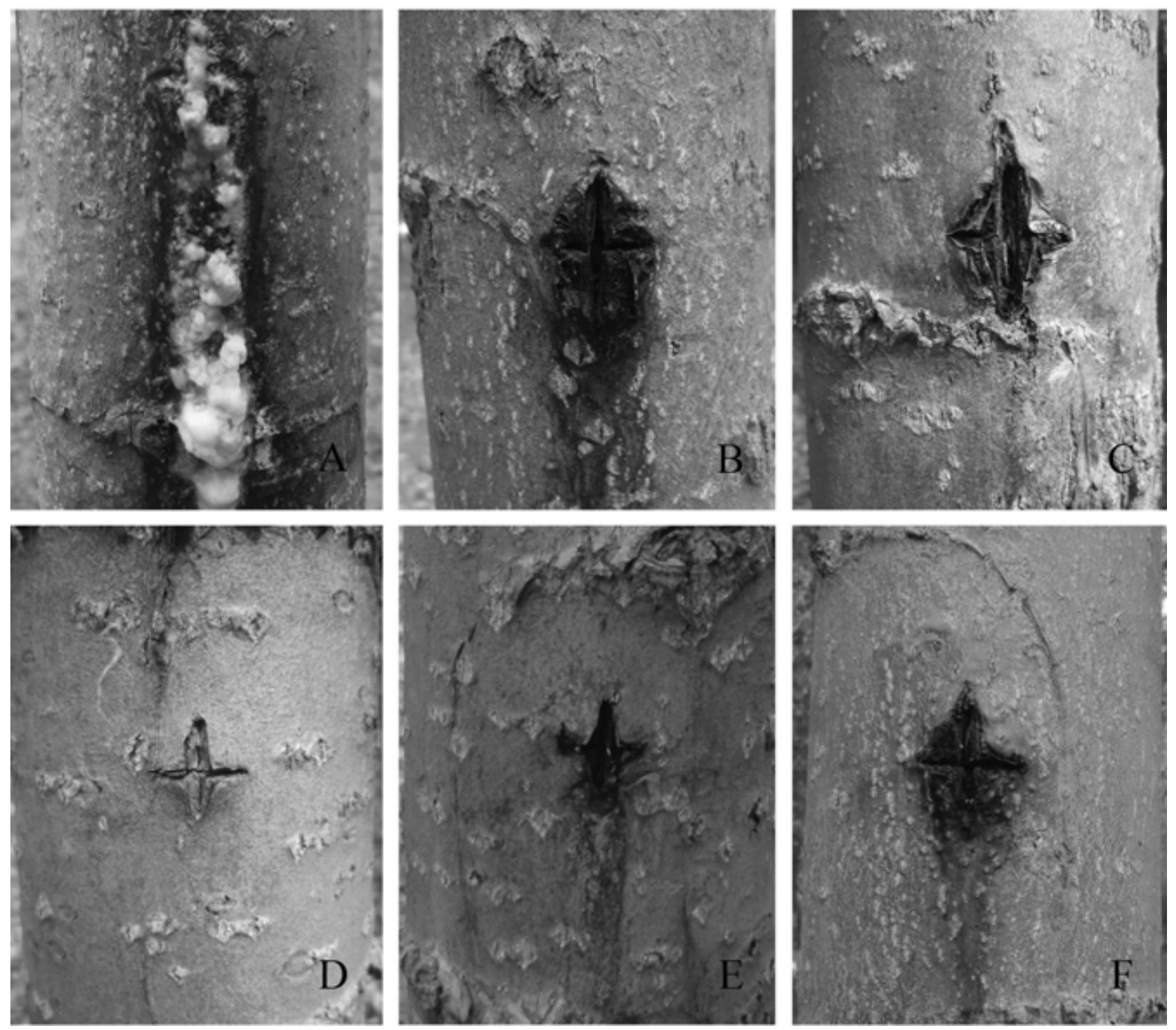

Fig. 2. Pathogenicity tests in the field on trees of Populus $\times$ euramericana 'Zhonglin 46'. A, Lonsdalea subsp. populi N-5-1; B, L. subsp. quercina ATCC 29281'; C, L. quercina subsp. iberica LMG 26264'; D, control; E, Brenneria populi NCPPB 4299; F, L. quercina subsp. britannica LMG $26267^{\top}$. Symptoms are 10 days after inoculation. 
and the $B$. quercina pv. lupinicola strains, with strong bootstrap support (99\%) separating them from the other species. This cluster is further divided into four subgroups, with the five poplar isolates forming a single clade with the type strain of $L$. quercina subsp. populi (supported with a bootstrap value of $78 \%$ ), and the $B$. quercina pv. lupinicola strains clustering with L. quercina subsp. quercina strains (with a bootstrap value of 74\%). The strains of $L$. quercina subsp. iberica and L. quercina subsp. britannica form the other two subgroups.

In pairwise comparisons of the gapA gene sequences, the five poplar isolates obtained in China had 99 to $100 \%$ nucleotide similarity to each other and 99.5, 94.6, 96.4, and 95.9\% nucleotide similarities with L. quercina subsp. populi $\mathrm{LMG} 27349^{\mathrm{T}}, L$. quercina subsp. quercina $\mathrm{LMG} 2724^{\mathrm{T}}$, L. quercina subsp. iberica LMG $26264^{\mathrm{T}}$, and L. quercina subsp. britannica LMG $26267^{\mathrm{T}}$, respectively. With the other species tested in this study, gapA gene sequence similarities were 76 to $89 \%$. Topology of the gapA phylogenetic tree (Fig. 4) is similar to the phylogenetic tree based on $16 \mathrm{~S}$ rRNA gene sequences for the L. quercina clade, with this clade being divided into the same four subgroups, with bootstrap support values of 93 to $99 \%$.

In the MLSA phylogenetic tree (Fig. 5) based on concatenated partial sequences of $g y r B, \operatorname{rpoB}, \operatorname{infB}$, and $a t p D$ genes, the poplar isolates are contained in a single cluster with the type strain of $L$.

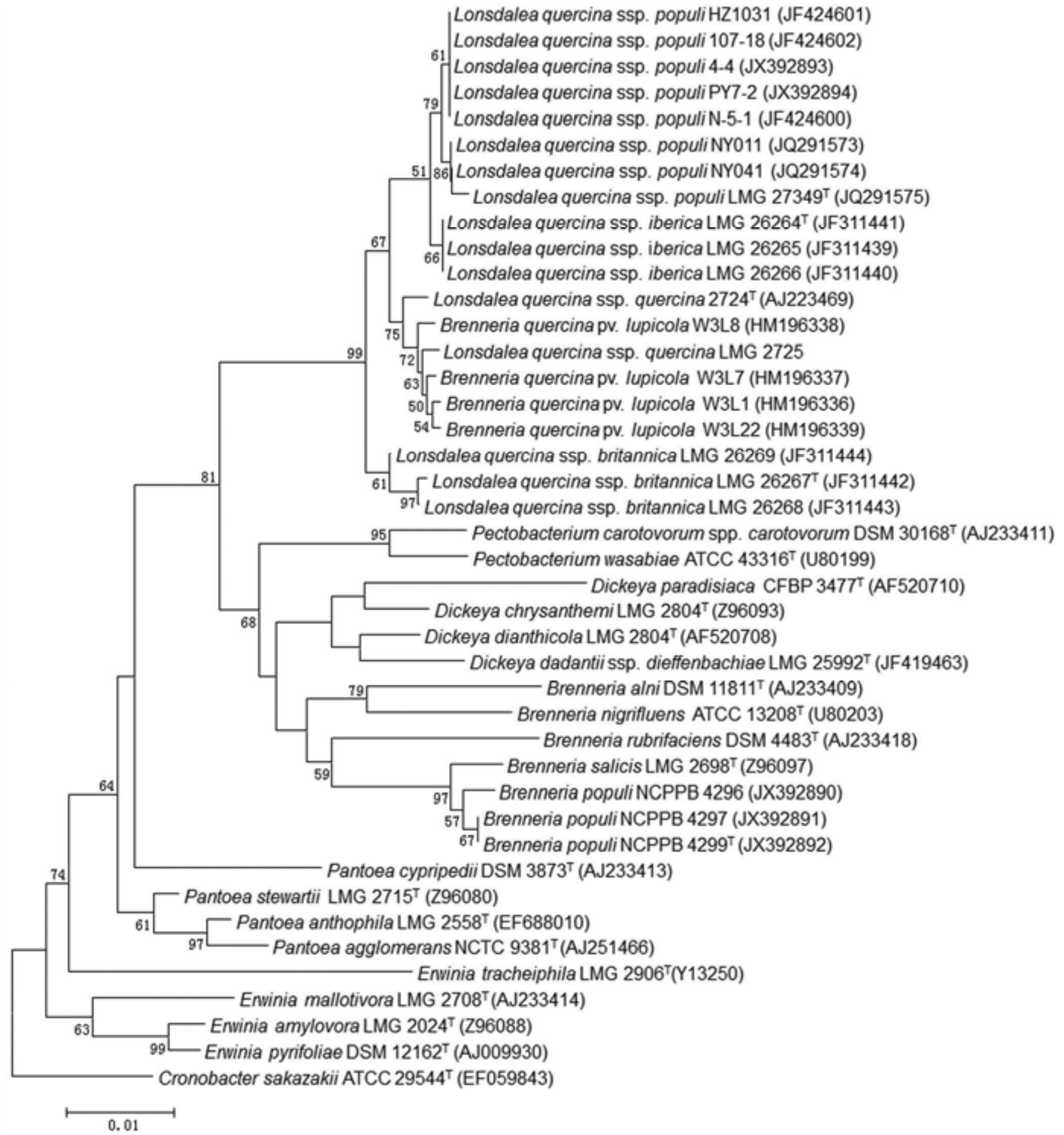

Fig. 3. Maximum likelihood tree based on almost complete $16 \mathrm{~S}$ ribosomal RNA gene sequences of members of Lonsdalea and of phylogenetically related species. Bootstrap percentage values based on 1,000 resampled data sets are shown at the nodes; only values above $50 \%$ are given. Cronobacter sakazakii is included as outgroup. The scale bar indicates a 0.01 nucleotide changes per site. 
quercina subsp. populi $\mathrm{LMG} 27349^{\mathrm{T}}$ (with $100 \%$ bootstrap support), distinct from the other three $L$. quercina subspecies. The same topology was observed in single nucleotide-based trees (data not shown). Based on the gapA, gyrB, $r p o B$, infB, and atpD gene sequence data, the poplar isolates obtained in China should be classified as L. quercina subsp. populi.

DNA-DNA hybridization and DNA G + C content. The three poplar isolates N-5-1, HZ1031, and 4-4 from China displayed a high DNA-DNA relatedness to each other $(90 \pm 5 \%)$ and to the type strain of L. quercina subsp. populi $\mathrm{LMG} 27349^{\mathrm{T}}(92 \pm 2 \%$ with N-5-1). DNA-DNA relatedness values to the type strains of other L. quercina subspecies were close to the recommended spe- cies delineation value of $70 \%$ (28); specifically, $67 \pm 5 \%$ with L. quercina subsp. quercina ATCC $29281^{\mathrm{T}}, 66 \pm 10 \%$ with L. quercina subsp. britannica LMG $26267^{\mathrm{T}}$, and $66 \pm 12 \%$ with $L$. quercina subsp. iberica LMG $26264^{\mathrm{T}}$. The DNA-DNA hybridization data confirm that the poplar isolates obtained in China are members of L. quercina subsp. populi. The $\mathrm{G}+\mathrm{C}$ content of the five poplar isolates obtained in this study was 54.5 to $54.9 \mathrm{~mol} \%$, which was previously observed for strains belonging to L. quercina (54.5 to $55.1 \mathrm{~mol} \%)(5)$.

Fatty acid analysis. The major fatty acids of the five bacterial poplar isolates N-5-1, 107-18, 4-4, HZ1031, and PY7-2 and of $L$. quercina subsp. populi $\mathrm{LMG} 27349^{\mathrm{T}}$ were $\mathrm{C}_{14: 0}, \mathrm{C}_{16: 0}, \mathrm{C}_{17: 0}$ cyclo,

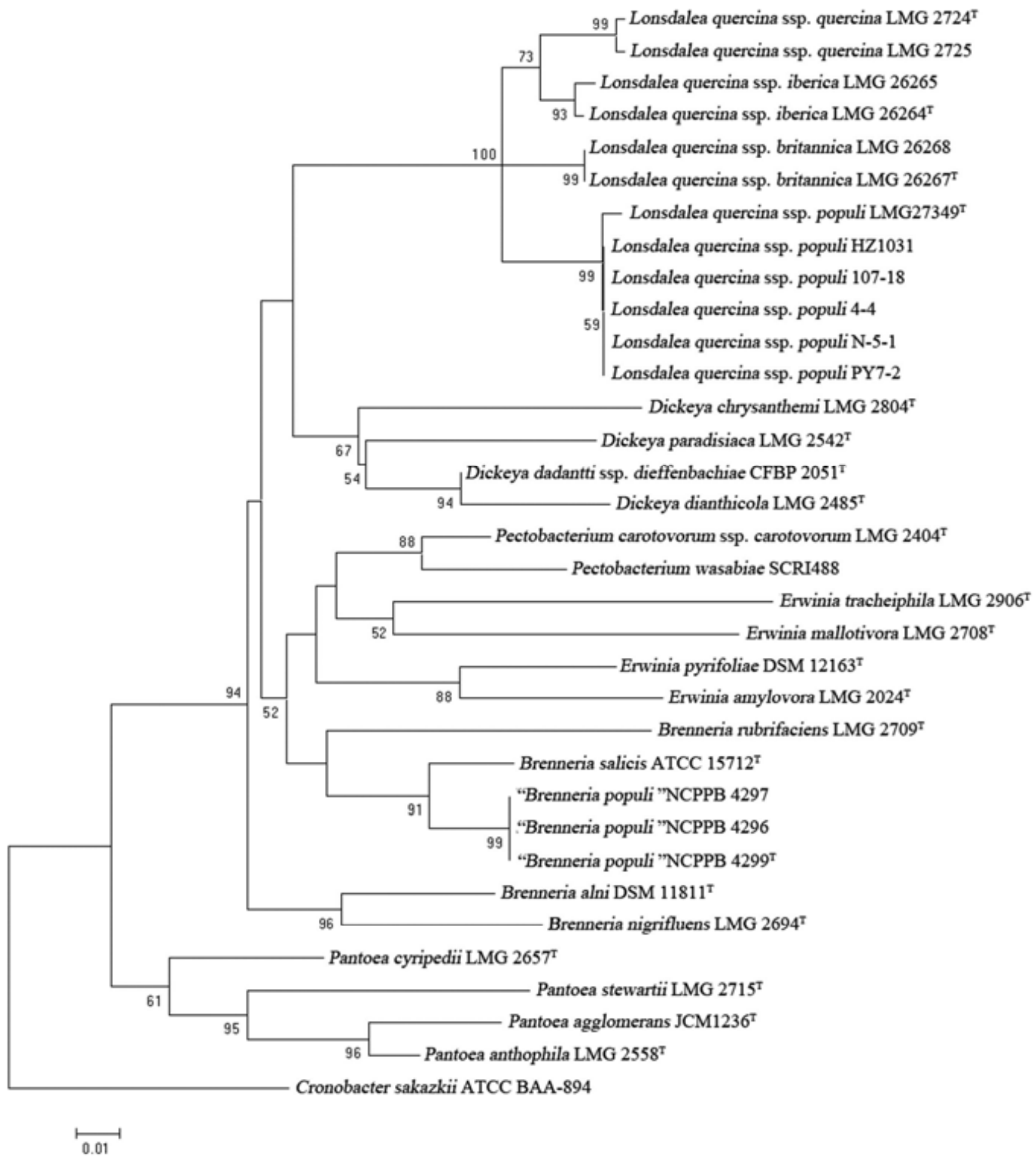

Fig. 4. Maximum likelihood tree based on gapA gene sequences of members of Lonsdalea and of phylogenetically related species. Bootstrap percentage values based on 1,000 resampled data sets are shown at the nodes; only values above $50 \%$ are given. Cronobacter sakazakii is included as outgroup. The scale bar is 0.01 nucleotide changes per site. 
and summed features 2 (iso- $\mathrm{C}_{16: 1}$ or $\left.\mathrm{C}_{14: 0} 3-\mathrm{OH}\right)$, and $3\left(\mathrm{C}_{16: 1} \omega 7 \mathrm{c}\right.$ or iso- $\left.\mathrm{C}_{15: 0} 2-\mathrm{OH}\right)$. The peak areas percentages of the fatty acids are presented in Table 3 . The percentages of the fatty acids $\mathrm{C}_{14: 0}$, $\mathrm{C}_{16: 0}, \mathrm{C}_{17: 0}$ cyclo, and $\mathrm{C}_{19: 0}$ cyclo were similar to those of the type strains of the other subspecies of Lonsdalea, and allow differentiation of Lonsdalea strains from B. salicis (LMG 2698 ${ }^{\mathrm{T}}$ ), Dickeya chrysanthemi (LMG $2804^{\mathrm{T}}$ ), and Pectobacterium carotovorum subsp. carotovorum (LMG $2404^{\mathrm{T}}$ ).

Phenotypic tests. Phenotypic characteristics enabling differentiation of Lonsdalea quercina subsp. populi from three other subspecies of L. quercina are listed in Table 4. Poplar isolates N-5-1, 107-18, 4-4, HZ1031, and PY7-2 were gram-negative, nonsporulating, motile short rods ( 0.5 to 1.0 by 1.0 to $2.0 \mu \mathrm{m})$ that occurred singly, in pairs, or in groups and had four peritrichous flagella. On TSA, the isolates produced circular, domed, convex, and smooth, white to cream-yellow colonies, with entire margins, 0.8 to $1 \mathrm{~mm}$ in size after $24 \mathrm{~h}$ of growth at $30^{\circ} \mathrm{C}$. They were facultatively anaerobic and had an optimum growth at $30^{\circ} \mathrm{C}$. They were negative for oxidase, amylase, phenylalanine dehydrogenase, $\beta$-galactosidase, arginine dihydrolase, lysine decarboxylase, ornithine decarboxylase, tryptophan deaminase, cellulosedegrading enzyme activity, and astaxanthin. Acetoin was not produced. They were positive for catalase, methyl-red, and the Voges-Proskauer tests, and utilized citrate. They did not produce $\mathrm{H}_{2} \mathrm{~S}$, urease, indole, or gelatinase. Nitrates were not reduced to nitrites. Acid was produced from $\mathrm{N}$-acetylglucosamine, arbutin, Dfructose, glycerol, D-glucose, D-mannitol, D-mannose, esculin ferric citrate, methyl- $\alpha$ D-glucopyranoside, D-ribose, salicin, Dsucrose, D-galactose, D-trehalose, and potassium gluconate. The following carbon sources were utilized at $28^{\circ} \mathrm{C}$ : $N$-acetyl-D-

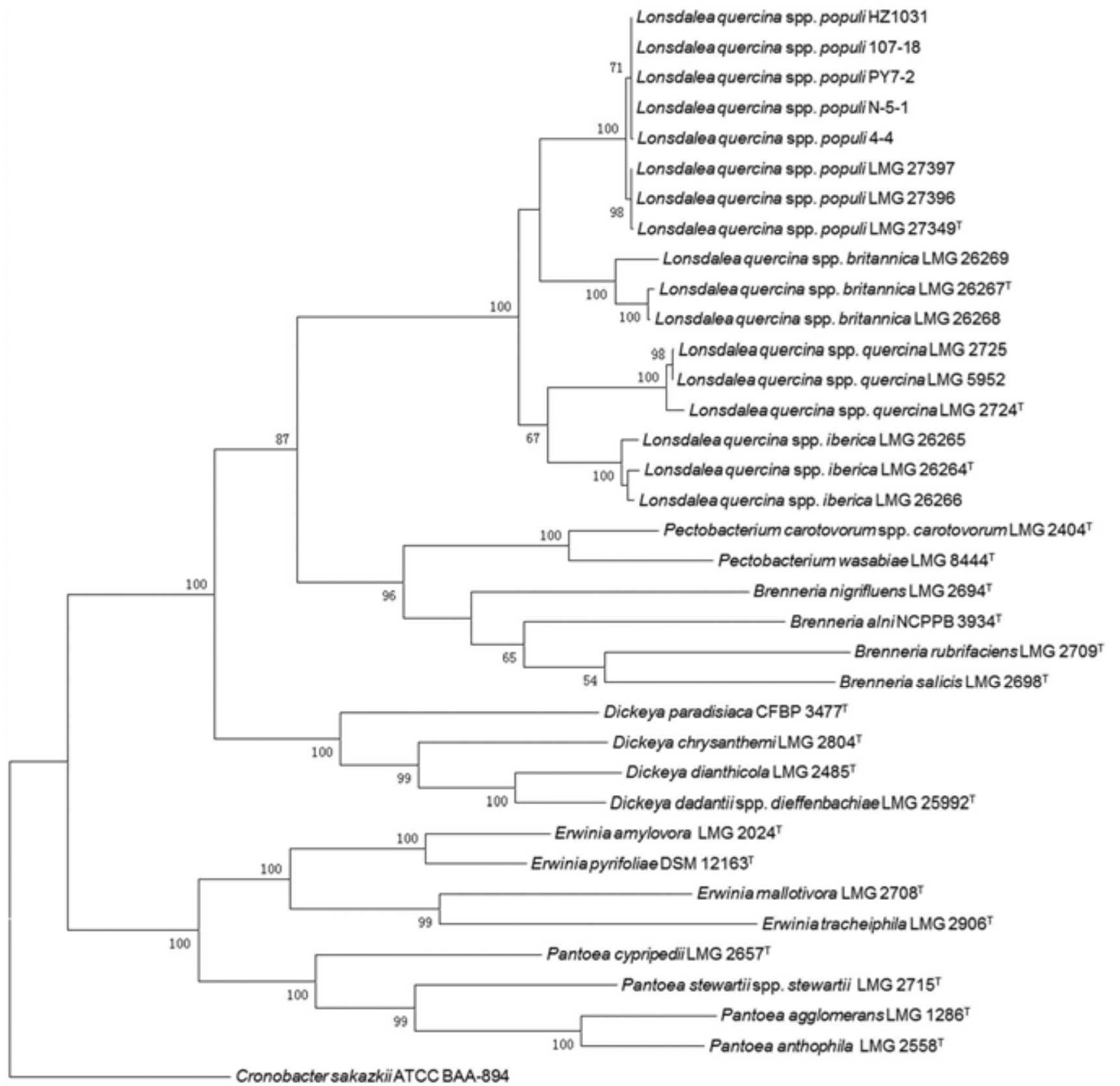

$\stackrel{\longmapsto}{\longmapsto}$

Fig. 5. Maximum likelihood tree based on concatenated partial gyrB, $r p \circ B$, atp $D$, and infB gene sequences of members of $L o n s d a l e a$ and of phylogenetically related species. Bootstrap percentage values based on 1,000 resampled data sets are shown at the nodes; only values above $50 \%$ are given. Cronobacter sakazakii is included as outgroup and gene sequences were obtained from the genome sequencing database of GenBank. The scale bar is 0.01 nucleotide changes per site. 
glucosamine, D-fructose, D-galactose, D-glucose, D-mannitol, Dmannose, $\beta$-methyl-D-glucoside, D-psicose, D-trehalose, sucrose, pyruvic acid methyl-ester, succinic acid mono-methyl-ester, succinic acid, D-gluconic acid, bromosuccinic acid, L-aspartic acid, glycerol, and D-glucose-6-phosphate. The following carbon sources were not utilized at $28^{\circ} \mathrm{C}$ : citric acid, $\alpha$-keto glutaric acid, dextrin, glycogen, adonitol, L-arabinose, D-arabitol, D-cellobiose, erythritol, L-fucose, gentiobiose, inositol, lactose, lactulose, maltose, turanose, D-melibiose, L-rhamnose, D-sorbitol, D-raffinose, formic acid, DL-lactic acid, L-glutamic acid, L-histidine, Lleucine, xylitol, galacturonic acid, and L-serine.

\section{Discussion}

In a preliminary report by He et al. (13) in 2009, strains of fungi and bacteria were isolated from diseased poplars in China. How- ever, as some fungal stromata appeared around the lesions of the poplar cankers, fungi were thought to be the causal agent and, therefore, isolation focused on fungi. Although several fungi were isolated, only two bacterial isolates were obtained. In addition, inoculation tests with the isolates, performed only in a greenhouse, revealed that an isolate of $F$. solani induced some symptoms, whereas two bacterial isolates and several other fungi were not pathogenic to water-cultured excised stems. Subsequent inoculation with $F$. solani in field studies revealed no typical symptoms in the inoculated trees. Based on the report of a canker on Populus $\times$ euramericana in Spain caused by B. populi, a genus that contains causal agents of diseases on various trees, we decided to investigate more samples of diseased poplar in China and use different isolation methods. As a result, more bacterial isolates, including the pathogenic ones, were obtained.

Table 3. Fatty acid composition (percentage of peak areas) of Lonsdalea quercina subsp. populi, L. quercina subsp. quercina, L. quercina subsp. iberica, L. quercina subsp. britannica, and selected type strains of Brenneria, Dickeya, and Pectobacterium

\begin{tabular}{|c|c|c|c|c|c|c|c|c|}
\hline \multirow[b]{2}{*}{ Fatty acid } & \multicolumn{8}{|c|}{ Species $^{\mathrm{a}}$} \\
\hline & 1 & 2 & 3 & 4 & 5 & 6 & 7 & 8 \\
\hline \multicolumn{9}{|l|}{ Saturated fatty acids } \\
\hline $12: 0$ & $0.84(0.01)$ & $0.82(0.02)$ & $0.75(0.05)$ & $0.0(0.00)$ & $0.82(0.07)$ & 4.03 & 0.33 & 9.12 \\
\hline 14:0 & $11.70(0.18)$ & $12.43(0.11)$ & $10.84(0.18)$ & $11.49(0.29)$ & $10.34(0.34)$ & 5.35 & 6.84 & 1.41 \\
\hline $16: 0$ & $32.75(1.10)$ & $31.80(0.26)$ & $31.57(0.13)$ & $34.68(0.38)$ & $32.04(0.16)$ & 29.04 & 26.65 & 24.28 \\
\hline 18:0 & $0.33(0.08)$ & $0.19(0.01)$ & $1.42(0.32)$ & $1.89(0.07)$ & $5.02(1.48)$ & 0.00 & 0.00 & 0.00 \\
\hline \multicolumn{9}{|l|}{ Unsaturated fatty acids } \\
\hline $18: 1 \omega 7 \mathrm{c}$ & $4.52(0.14)$ & $4.87(0.18)$ & $10.73(0.27)$ & $8.55(0.15)$ & $11.15(0.34)$ & 15.32 & 16.21 & 13.12 \\
\hline \multicolumn{9}{|l|}{ Cyclopropane fatty acids } \\
\hline $17: 0$ & $9.99(0.02)$ & $16.74(0.40)$ & $9.08(0.71)$ & $16.05(1.82)$ & $8.73(0.21)$ & 9.58 & 0.7 & 0.0 \\
\hline 19:0 & $0.74(0.00)$ & $2.14(0.09)$ & $1.8(0.07)$ & $4.86(0.04)$ & $2.44(0.09)$ & 0.53 & 0.0 & 0.0 \\
\hline \multicolumn{9}{|l|}{ Sum in feature } \\
\hline $2: 16: 1$ iso $\mathrm{I} / 14: 03 \mathrm{OH}$ & $11.69(1.10)$ & $11.45(0.78)$ & $9.43(0.77)$ & $9.47(0.23)$ & $9.24(1.79)$ & 11.13 & 12.03 & 14.09 \\
\hline $3: 16: 1 \omega 7 \mathrm{c} /$ iso-C15:0 2-OH & $26.62(0.05)$ & $18.83(0.77)$ & $19.47(1.63)$ & $10.09(0.32)$ & $17.47(0.06)$ & 23.21 & 34.72 & 30.85 \\
\hline
\end{tabular}

a Strains: 1, L. quercina subsp. populi $\left(\right.$ LMG $\left.27349^{\mathrm{T}}\right) ; 2$, L. quercina subsp. populi $(\mathrm{N}-5-1) ; 3$, L. quercina subsp. iberica $\left(\mathrm{LMG}^{\left.26264^{\mathrm{T}}\right) ; 4, \text { L. quercina }}\right.$ subsp. britannica (LMG 26267 $)$; 5, L. quercina subsp. quercina (ATCC 29281 ${ }^{\mathrm{T}}$ ); 6, Brenneria salicis (LMG 2698 ${ }^{\mathrm{T}}$ ); 7, Dickeya chrysanthemi $($ LMG $2804^{\mathrm{T}}$ ); and 8, Pectobacterium carotovorum subsp. carotovorum (LMG 2404 ${ }^{\mathrm{T}}$ ). Mean (\%) and standard deviation of three extractions. Results of Brenneria salicis (LMG 2698 ${ }^{\mathrm{T}}$ ), Dickeya chrysanthemi (LMG 2804 ${ }^{\mathrm{T}}$ ), and Pectobacterium carotovorum subsp. carotovorum (LMG $2404^{\mathrm{T}}$ ) were taken from Brady et al. (5). Other results were obtained in this study.

Table 4. Phenotypic characteristics enabling differentiation of Lonsdalea quercina subsp. populi from three other subspecies of $L$. quercina

\begin{tabular}{|c|c|c|c|c|c|}
\hline \multirow[b]{2}{*}{ Characteristic } & \multicolumn{5}{|c|}{ Subspecies $^{\mathbf{a}}$} \\
\hline & 1 & 2 & 3 & 4 & 5 \\
\hline Voges-Proskauer & $\mathrm{v}$ & + & - & + & + \\
\hline \multicolumn{6}{|l|}{ Acid from ${ }^{b}$} \\
\hline Glycerol & - & + & + & + & + \\
\hline D-Galactose & + & + & - & + & + \\
\hline D-Trehalose & - & - & + & + & + \\
\hline D-Turanose & + & + & + & - & - \\
\hline Potassium gluconate & + & - & + & + & + \\
\hline D-Raffinose & $\mathrm{w}$ & - & - & - & - \\
\hline \multicolumn{6}{|l|}{ Carbon source utilization $^{c}$} \\
\hline D-Raffinose & - & + & - & - & - \\
\hline D-Trehalose & - & + & + & + & + \\
\hline Turanose & + & + & + & - & - \\
\hline Pyruvic acid methyl-ester & - & - & - & + & + \\
\hline Succinic acid mono-methyl-ester & - & - & - & + & + \\
\hline Citric acid & + & + & + & - & - \\
\hline Formic acid & - & + & + & - & - \\
\hline$\alpha$-Keto glutaric acid & - & + & + & + & + \\
\hline DL-Lactic acid & - & + & + & - & - \\
\hline Succinic acid & - & + & + & + & + \\
\hline L-Glutamic acid & - & - & + & + & - \\
\hline L-Histidine & + & - & - & - & - \\
\hline L-Leucine & + & - & - & - & - \\
\hline L-Phenylalanine & + & - & - & - & $\ldots$ \\
\hline L-Threonine & + & - & - & - & $\ldots$ \\
\hline
\end{tabular}

a Strains: 1, L. quercina subsp. quercina (number of strains $[n]=2$, ATCC 29281 ${ }^{\mathrm{T}}$, LMG 2725); 2, L. quercina subsp. iberica $\left(n=2\right.$, LMG $26264^{\mathrm{T}}$, LMG 26265); 3, L. quercina subsp. britannica $\left(n=2\right.$, LMG 26267 , LMG 26268); 4, L. quercina subsp. populi $\left(n=1\right.$, LMG $\left.27349^{\mathrm{T}}=\mathrm{NY} 060^{\mathrm{T}}\right)$; and $5, L$. quercina subsp. populi $(n=5$, N-5-1, HZ1031, 107-18, 4-4, and PY7-2). Symbols: $+=$ positive, $-=$ negative, $\mathrm{v}=$ variable reaction, and $\mathrm{w}=\mathrm{weak}$.

b API 50CHB/E.

${ }^{c}$ Biolog GN2. 
Nine different fungal colony types were isolated, with one (DQZ2-3) being dominant, representing $49.1 \%$ of all fungal isolates. Strain DQZ2-3, isolated from canker tissue of P. $\times$ euramericana 74/76, Puyang Henan, was identified as $F$. solani based on its morphology and molecular characteristics. Colonies similar to those of DQZ2-3 were consistently isolated from diseased poplar bark collected from different locations. This result was congruent with the preliminary report (13). However, when $F$. solani isolates (MZ01 from our previous study and DQZ2-3) were tested in a field experiment, only some water or mucus appeared at inoculation sites of $P . \times$ euramericana Zhonglin 46 and $74 / 76$ at 3 to 10 days after inoculation, and a lesion with a diameter less than $1 \mathrm{~cm}$ was observed in the margin of the inoculated wound (data not shown). Subsequently, lesions did not expand and began to heal, which is in contrast to the typical symptoms of naturally infected trees (bark canker with abundant white, sour exudates). These results showed that $F$. solani was not the causal agent of $P$. $\times$ euramericana canker in China. However, because $F$. solani expressed weak pathogenicity to $P . \times$ euramericana and frequently occurred in canker tissues, its role in canker disease development needs to be studied further.

In this study, 3-, 4-, and 5-year-old field trees of $P . \times$ euramericana $74 / 76$ or Zhonglin 46 were chosen for inoculation with pure cultures of L. quercina from poplar in China. The results of 4 years of field inoculation experiments revealed that trees inoculated with the bacterial isolate N-5-1 exhibited typical symptoms of naturally infected trees. Isolate 4-4 was also pathogenic to $P$. $\times$ euramericana, as shown in 2 years of field inoculation experiments. The same bacteria obtained through reisolation of the inoculated diseased trees reproduced the typical symptoms when inoculated into 5-year-old trees again, whereas the controls remained healthy. Inoculation of N-5-1 and the fungal isolate DQZ2-3 resulted in symptoms similar to those of N-5-1 only. Therefore, this bacterium is the causal agent of poplar canker in China.

The three isolates that were pathogenic in the field tests (N-5-1, HZ1031, and 4-4) and two additional isolates (PY7-2 and 107-18) were subjected to a polyphasic taxonomic study and identified as L. quercina subsp. populi. In 2011, based on 16S rRNA gene sequencing, MLSA, phenotypic testing, and DNA-DNA hybridizations, B. quercina was reclassified into a novel genus, Lonsdalea gen. nov. (5). This genus currently consists of one species, $L$. quercina, that is composed of four subspecies (L. quercina subspp. quercina, iberica, britannica, and populi). Strains of this species are proven or suspected pathogens that initially were believed to be restricted to Quercus spp., until a bacterial disease (drippy pod of white lupine) was reported to be caused by B. quercina pv. lupinicola (16). In the 16S rRNA nucleotide sequence tree (Fig. 3), four strains of $B$. quercina pv. lupinicola originating from the United States form a single branch with a bootstrap value of $74 \%$ with two strains of L. quercina subsp. quercina, also originating from the United States. The results show that the causal agent of drippy pod of white lupine belongs to $L$. quercina and should be named $L$. quercina pv. lupinicola. It is notable that white lupine is an annual herbaceous plant host of L. quercina. Very recently, L. quercina subsp. populi was described based on isolates of bark canker of poplar trees in Hungary (25). The data obtained in this study show that the poplar isolates obtained in China are very similar to those obtained in Hungary.

The canker on $P . \times$ euramericana in Spain caused by B. populi is somewhat similar to the disease observed in China. In this study, $B$. populi NCPPB 4299 did not cause symptoms on trees of $P . \times$ euramericana Zhonglin 46 under the conditions used. Three strains isolated from P. $\times$ euramericana cankers in Spain (NCPPB 4296, 4297, and 4299) were selected for phylogenetic analysis based on $16 \mathrm{~S}$ rRNA and gapA gene sequences. The phylogeny trees revealed that these strains cluster close to the type strain of $B$. salicis and distant from the poplar canker isolates from China and Hungary. These results suggest that the pathogen of poplar canker in Spain is different from the pathogen of poplar canker in China.

Recently, analysis of multiple protein-encoding housekeeping genes, including gapA, $r p o B, \operatorname{gyr} B$, atpD, and $\inf B$, and the MLSA of such genes, have become widely applied tools for the investigation of bacterial taxonomic relationships $(5-7,17,19,27)$. The high degree of sequence divergence of housekeeping genes is superior for identification purposes, because they are less conserved than rRNA genes. MLSA, like DNA-DNA hybridization, is a suitable technique for species delineation and for assessing relationships at the intraspecific level (19). In this study, the trees based on single nucleotide gene sequences of $\operatorname{gap} A$ (Fig. 4), gyrB, $\operatorname{rpoB}$, atpD, and inf $B$ have groupings largely similar to those of the concatenated nucleotide-sequence-based tree ( $g y r B, r p o B, a t p D$, and infB).

$P . \times$ euramericana $74 / 76$ is one of the most widely grown poplar cultivars in China. The bacterial canker disease observed to occur in northern Henan and western Shandong on such trees often caused a great loss. The occurrence of the bacterial canker disease on $P . \times$ euramericana 74/76 emerged as a barrier for expanding cultivation of the poplar trees. It is not clear how the disease spreads and where the pathogen overwinters. It was reported that the drippy pod bacterial disease can be spread by wind, splashing rain, and the feeding activities of insects $(16,21)$. In this study, several insects were observed on the diseased plants in China. It is possible that they act as a vector for the bacterial pathogen. In our study of endophytic bacteria, only one isolate (107-18) of $L$. quercina subsp. populi was obtained from more than 100 bark samples of $P$. $\times$ euramericana asymptomatic trees from 2010 to 2011. Therefore, it is not likely that L. quercina subsp. populi is an endophytic bacterium in poplars.

Thus far, the canker observed in China naturally occurred only on $P . \times$ euramericana $74 / 76, P . \times$ euramericana Zhonglin $46, P$. deltoides Zhonghe 1 , and $P . \times$ euramericana Robusta. It is unclear from the literature which $P . \times$ euramericana cultivar is infected in Hungary. Also, it is unclear whether other poplar species and cultivars can be infected. A detailed comparison of the isolates of China and Hungary is needed and may help to trace the source of the bacterial pathogen.

\section{Acknowledgments}

This research was supported by China National Forestry Department Public Benefit Research Foundation (201104054). The BCCM/LMG Bacteria Collection is supported by the Federal Public Planning Service-Science Policy, Belgium.

\section{Literature Cited}

1. Ausubel, F. M. 1988. Current Protocols in Molecular Biology. Greene Pub. Associates, New York.

2. Biosca, E. G., González, R., López-López, M., Soria, S., Montón, C., PérezLaorga, E., and López, M. M. 2003. Isolation and characterization of Brenneria quercina causal agent for bark canker and drippy nut of Quercus spp. in Spain. Phytopathology 93:485-492.

3. Biosca, E. G., González, R., López-López, M. J., Martín, S. Y., and López, M. M. 2002. Bacterias fitopatógenas del género Brenneria (Erwinia) identificadas en España. Phytoma-España 138:73-77.

4. Biosca, E. G., Martín, S., Zuriaga. P., Montón, C., López-Ocaña, L., and López, M. M. 2006. Characterization of Brenneria sp. from poplar cankers in Spain. Pages 385-389 in: Modern Multidisciplinary Applied Microbiology: Exploiting Microbes and Their Interactions. Wiley-VCH Verlag GmbH \& Co. KGaA Publishing, Weinheim, Germany.

5. Brady, C. L., Cleenwerck, I., Denman, S., Venter, S. N., Rodríguez-Palenzuela, P., Coutinho, T. A., and Vos, P. D. 2012. Proposal to reclassify Brenneria quercina (Hildebrand \& Schroth 1967) Hauben et al. 1999 into a novel genus, Lonsdalea gen. nov., as Lonsdalea quercina comb. nov., descriptions of Lonsdalea quercina subsp. quercina comb. nov., Lonsdalea quercina subsp. iberica subsp. nov. and Lonsdalea quercina subsp. britannica subsp. nov., emendation of the description of the genus Brenneria, reclassification of Dickeya dieffenbachiae as Dickeya dadantii subsp. dieffenbachiae comb. nov., and emendation of the description of Dickeya dadantii. Int. J. Syst. Evol. Microbiol. 62:1592-1602.

6. Brady, C., Cleenwerck, I., Venter, S., Vancanneyt, M., Swings, J., and Coutinho, T. 2008. Phylogeny and identification of Pantoea species associated with plants, humans and the natural environment based on multilocus sequence analysis (MLSA). Syst. Appl. Microbiol. 31:447-460.

7. Brown, E. W., Davis, R. M., Gouk, C., and Van der Zwet, T. 2000. Phylogenetic relationships of necrogenic Erwinia and Brenneria species as revealed by glyceraldehyde-3-phosphate dehydrogenase gene sequences. Int. J. Syst. Evol. Microbiol. 50:2057-2068.

8. De Ley, J., Cattoir, H., and Reynaerts, A. 1970. The quantitative measurement of DNA hybridization from renaturation rates. Eur. J. Biochem. 12:133-142. 
9. Dong, X. Z., and Cai, M. Y. 2001. Pages 354-370 in: Systematical Determinative Manual of Common Bacteriology. Science Press, Beijing, China.

10. González, R., López-López, M. J., Biosca, E. G., López, F., Santiago R., and López, M. M. 2002. First report of bacterial deep bark canker of walnut caused by Brenneria rubrifaciens in Europe. Plant Dis. 86:696.

11. Hauben, L., Moore, E. R. B., Vauterin, L., Steenackers, M., Mergaert, J., Verdonck, L., and Swings, J. 1998. Phylogenetic position of phytopathogens within the Enterobacteriaceae. Syst. Appl. Microbiol. 21:384-397.

12. Hauben, L., and Swings, J. 2005. Genus IV. Brenneria Hauben, Moore, Vauterin, Steenackers, Mergaert, Verdonck, and Swings 1999, $1^{\text {VP }}$. Pages 628-633 in: Bergey's Manual of Systematic Bacteriology. D. J. Brenner, N. R. Krieg, J. R. Staley, and G. M. Garrity, eds. Springer, New York.

13. He, W., Ren, F. J., Guo, L. M., Li, Y., and Chang J. P. 2009. Pathogen identification of Populus $\times$ euramericana canker disease. Sci. Silv. Sin. 45:104108.

14. Lane, D. J. 1991. 16S/23S rRNA sequencing. Pages 115-175 in: Nucleic Acid Techniques in Bacterial Systematics. M. Goodfellow, ed. John Wiley \& Sons, Chichester, England.

15. Loreti, S., De, Simone, D., and Gallelli, A. 2008. Detection and identification of Brenneria nigrifluens, the causal agent of the shallow bark canker of walnut, by PCR amplification. J. Phytopathol. 156:464-469.

16. Lu, S. E., and Gross, D. C. 2010. Drippy pod of white lupine: a new bacterial disease caused by a pathovar of Brenneria quercina. Plant Dis. 94:14311440.

17. Ma, B., Hibbing, M. E., Kim, H. S., Reedy, R. M., Yedidia, I., Breuer, J., Breuer, J., Glasner, J. D., Perna, N. T., Kelman, A., and Charkowski, A. O. 2007. Host range and molecular phylogenies of the soft rot enterobacterial genera Pectobacterium and Dickeya. Phytopathology 97:1150-1163.

18. Marmur, J. 1961. A procedure for the isolation of deoxyribonucleic acid from microorganisms. J. Mol. Biol. 3:208-218.

19. Martens, M. Dawyndt, P., Coopman, R., Gillis M., De Vos, P., and Willems, A. 2008. Advantages of multilocus sequence analysis for taxonomic studies: a case study using 10 housekeeping genes in the genus Ensifer (including former Sinorhizobium). Int. J. Syst. Evol. Microbiol. 58:200-214.

20. MIS Operating Manual. 1999. Sherlock Microbial Identification System, Version 3.0. MIDI, Inc. Newark, DE.

21. Myhre, E. A. 1988. Effects of Lygus spp. (Hemiptera: Miridae) on Mediterranean white lupin (Lupinus albus). M.S. thesis, Entomology, Washington State University, Pullman.

22. Poza-Carrión, C., Aguilar, I., Gallego, F. J., Nuñez-Moreno, Y., Biosca, E. G., González, R., López, M. M., and Rodríguez-Palenzuela, P. 2008. Brenneria quercina and Serratia spp. isolated from Spanish oak trees: molecular characterization and development of PCR primers. Plant Pathol. 57:308 319 .

23. Tamura, K., Peterson, D., Peterson, N., Stecher, G., Nei, M., and Kumar, S. 2011. MEGA5: molecular evolutionary genetics analysis using maximum likelihood, evolutionary distance, and maximum parsimony methods. Mol. Biol. Evol. 28, 2731-2739.

24. Thompson, J. D., Higgins, D. G., and Gibson, T. J. 1994. CLUSTAL W: improving the sensitivity of progressive multiple sequence alignment through sequence weighting, position-specific gap penalties and weight matrix choice. Nucleic Acids Res. 22:4673-4680.

25. Tóth, T., Lakatos, T. and Koltay, A. 2013. Lonsdalea quercina subsp. populi subsp. nov., isolated from bark canker of poplar trees. Int. J. Syst. Evol. Microbiol. 63:2309-2313.

26. Wang, D. S. 1977. Bacteria Taxonomy. Science Press, Beijing.

27. Wang, L. T., Lee, F. L., Tai, C. J., and Kasai, H. 2007. Comparison of gyrB gene sequences, 16S rRNA gene sequences and DNA-DNA hybridization in the Bacillus subtilis group. Int. J. Syst. Evol. Microbiol. 57:1846-1850.

28. Wayne, L.G., Brenner, D. J., Colwell, R. R., Grimont, P. A.. D., Kandler, O., Krichevsky, M. I., Moore, L. H., Moore, W. E. C., Murray, R. G. E., Stackebrandt, E., Starr, M. P., and Trüper, H. G. 1987. Report of the ad hoc committee on reconciliation of approaches to bacterial systematics. Int. J. Syst. Bacteriol. 37:463-464. 